\title{
Osmanlı İmparatorluğu'nda Girişimcilik: Klasik Dönem Üzerine Bir Çalışma
}

\author{
Yasin AKKUŞ*, Süleyman Ahmet MENTEŞ**
}

Öz

Osmanlı İmparatorluğu klasik döneminde girișimcilik, ișletme bilimi bakış açısıyla yeterince incelenmemiştir. Hatta birçok eserde ya yok sayılmış ya da gayrimüslimlerin tekelinde olduğu iddia edilmiştir. Bu çalışma Osmanlı'nın klasik dönemindeki Müslüman tacirlerin girişimcilik konusunda gayet aktif olduğunu ve girişimcilik ortamının birçok Avrupa devletine kıyasla daha esnek olduğunu belirtmektedir. Osmanlı İmparatorluğu'nda sosyal refah sağlamanın adaletin bir boyutu olarak görülmüş ve tüm iktisadi kararların bu amaçla alınmıștır. Bu yaklaşım hem Osmanlı’nın girişimcilik kültürü ve uygulamaları açısından belirleyici bir role sahiptir hem de Osmanlı'nın klasik dönemindeki üstün iş ahlakı ve gelişmiş sosyal sorumluluk anlayıșını açıklamaktadır.

Anahtar Sözcükler: Osmanlı İmparatorluğu, Girişimcilik, Ticaret, Tüccar, Sosyal Sorumluluk, İş Ahlakı

\section{Entrepreneurship in the Ottoman Empire: A Study on Classical Period}

\section{Abstract}

Entrepreneurship in Ottoman Empire's classical period is not adequately studied from a Business Science perspective. Even in many works, it was ignored or it was the monopoly of non-Muslims. This study states that in the classical period of the Ottoman era Muslim merchants were very active in entrepreneurship and the entrepreneurial environment was more flexible than many European states. Social welfare in the Ottoman Empire was seen as a dimension of justice and all economic decisions were taken for this purpose. This approach has a decisive role not only in the Ottoman entrepreneurship culture and practices but also explains the advanced business ethics and advanced social responsibility practices of the Ottomans classical period.

Keywords: Ottoman Empire, Entrepreneurship, Trade, Merchant, Social Responsibility, Business Ethics

\section{Derleme Makale (Review Article)}

Geliş/Received: 19.03 .2018

Kabul/Accepted: 24.07 .2018

DOI: http://dx.doi.org/10.17336/igusbd.405820

* Uygulamalı Girișimcilik Eğitmeni, Tekirdağ Namık Kemal Üniversitesi, İ̉BF, Tekirdağ, Türkiye, E-posta: yasin akkus@yahoo.com ORCID ID https://orcid.org/0000-0003-3225-4251

** Doç. Dr., Tekirdağ Namık Kemal Üniversitesi, İỉBF, İșletme Bölümü Öğretim Üyesi, Tekirdağ, Türkiye, E-posta: ahmetmentes@yahoo.com ORCID ID https://orcid.org/0000-0001-7787-6287 
Y. Akkuş, S. A. Menteș, "Osmanlı İmparatorluğu'nda Girișimcilik: Klasik Dönem Üzerine Bir Çalıșma", İstanbul Gelişim Üniversitesi Sosyal Bilimler Dergisi, 5 (2), Ekim 2018, ss. 169-186.

\section{Giriş}

Gerek işletme kökenli bilim insanlarının tarihsel sürece gerektiği kadar değinmemesi gerekse sosyal bilimler içerisinde disiplinler arası çalışmaların yetersiz oluşu nedeniyle Türkiye'nin girişimcilik tarihi hak ettiği ilgiyi görmemiştir. İşletme literatüründeki çoğu eserde Türkiye'deki girişimcilik, 19. Yüzyıldan başlatılmaktadır. Bu tarihten önceki girişimcilik faaliyetleri yok sayılmakta (Aşkın, 2011, s. 62) ya da yabancıların ve gayrimüslimlerin tek elinde olduğu kabul edilmektedir (Tikici \& Aksoy, 2009, s. 44). Tarih bilimi alanında da daha çok Osmanlı İmparatorluğunun siyasi tarihi alanındaki çalışmalara ağırlık verilirken iktisat tarihi alanı ancak 1950'lerden sonra ilgi görmeye başladığı görülmektedir. Annales Okulunun Dünya iktisat tarihine ve Ömer Lütfi Barkan, Halil İnalcık, Mustafa Akdağ, Mehmet Genç, Suraiya Faroqhi, Ahmet Tabakoğlu, Şevket Pamuk gibi bilim insanlarının Türkiye'nin iktisat tarihine yaptıkları büyük katkılarla Osmanlı Devletinin iktisadi yapısı daha doğru olarak anlaşılmaya başlanmıştır (Kılıçbay, 1992, s. 333).

$\mathrm{Bu}$ çalışma ile Osmanlı İmparatorluğu'nun klasik ${ }^{1}$ dönemindeki girişimciliğin değerlendirilmesi amaçlanmaktadır. Avrupa'ya kıyasla Osmanlıdaki girişimcilik ortamının zayıf olduğu savı incelenecek ve Osmanlı girișimcisi tasvir edilecektir. Ayrıca, 19. Yüzyll öncesinde, Osmanlıdaki girişimcilik faaliyetlerinin çoğunlukla yabancılar ve gayrimüslimler tarafından gerçekleştirildiğini iddia eden görüşlerin geçerliliği değerlendirilecektir.

\section{Girişimcilik Kavramı ve Tarihçesi}

Girişimcilik tanımı günümüze gelinceye kadar değişik süreçlerden geçmiştir. Richard Cantillon² ${ }^{2}$ girișimciliği kar elde etmek üzere imkânlar arayan ve risk alan birey olarak tanımlarken; 20. yüzyılda Joseph A. Schumpeter bunu yenilik kavramı çerçevesinde yorumlayarak "yıkıcı girişimcilik" tanımı yapmıştır. 20. ve 21. yüzyılda girişimcilik denildiğinde daha çok Shumpeter'in bakış açısına paralel tanımlar anlaşılmaktadır. Ancak yenilik temelli girişimcilik tanımının, daha çok günümüzün bakış açısını yansıttığı ve daha sanayi devrimini yaşamamış bir dönem olan 15. ve 17. yüzyılları gerçek anlamda kapsamayacağı düşünülmektedir. Bu kapsamda, dönemin girişimcilik tanımını

\footnotetext{
${ }^{1}$ Osmanlının klasik dönemini tanımlayan değişik görüşler bulunmaktadır. İnalcık (2014: 188) klasik dönemi daha çok kuruluş dönemi ile birlikte ele almakta ve 14. yüzyıl ile 17. yüzyılın başları arasında sınırlandırmaktadır. Bu sınırlamanın, ticaret söz konusu olduğunda 18. yüzyıla kadar genişletildiği de görülmektedir (İnalcık 2014: 317). Bazı görüşler ise klasik döneme iktisadi açıdan yaklaşmakta ve 14.-16. yüzyıllar arası oluşan iktisadi yapının 19. yüzyılların başına kadar köklü bir değişiklik geçirmediğini iddia etmektedir (Genç 2012: 175). Yukarıdaki değerlendirmelere dayanarak; bu çalışmada, Osmanlı İmparatorluğunun klasik dönemi olarak daha çok 15. Yüzyılın ortalarında başlayan 17. yüzyılın başlarında son bulan dönem kastedilmektedir (Akkuş 2009: 35).

${ }^{2}$ Girişimcilik (Entrepreneur) tanımının J.B. Say tarafından ekonomiye kazandırıldığı savunulsa da ekonomik bir analizde ilk defa kullanan Cantillon'dur. Yine, "Essai sur la Nature du Commerce en Général (İng.: An Essay on EconomicTheory)” adlı eserinde Cantillon; girişimcilik kavramını tüccar (merchant) ve zanaatkâr (artisan) kavramları ile beraber ve bazen bunların yerine kullanmaktadır (Cantillon, 2010, s. 31-36).
} 
daha çok yansıttığı düşünülen Cantillon'un bakış açısı ile değerlendirmenin daha sağlıklı bir sonuç vereceği düşünülmektedir (Döm, 2015, s. 3). Ayrıca, Girişimci ve burjuva kavramları iktisadi bilimlerde sıklıkla birbirleri yerine kullanılmaktadır (Özer, 2001, s. 166). Bu yaygın anlayış ile girişimcinin hali vakti yerinde ve elit bir sınıfa ait birey olarak algılanması olağandır. Ancak Cantillon (2010, s. 31); taşradan aldığı/ürettiği ürünü kasabada, haftada bir veya iki kere kurulan pazara getirip satanlardan girişimci ve tüccar olarak bahseder. Buradan girișimcinin sadece belli bir sınıfa ait bir birey olarak tanımlamanın yanlış olduğu sonucu çıkarılabilir. Braudel (2004, s. 431), 18. yüzyll İngiltere'sinde bile birkaç bez tüccarı ve dış ticaret ile ilgilenen tüccarlardan başka büyük girişimcilerin azınlıkta olduğunu bilinmektedir. Ayrıca 18. yüzyılda Amsterdam'da en büyük firmaların çalışan sayısının 30 kişiyi geçmediğini de eklemektedir. Tüm bunlara dayanarak 15. yüzyıl ve 17. yüzyıl arasındaki girişim kavramı; belirli bir riski üstlenerek kar elde etme amacı güden, faaliyetleri çoğunlukla aile bireyleri tarafından gerçekleştirilen, zanaatkârlıkla veya iç ya da dış ticaretle uğraşan küçük ekonomik yapılar olarak tanımlanabilir. Bu girişimleri yapan ve daha sonra yöneten bireyler ise girişimci olarak adlandırılmaktadır. Tam bu noktada girişimci ile yatırımcı ${ }^{3}$ kavramını da ayırmakta fayda görülmektedir. Yatırımcı genellikle girişimciyi sermaye olarak finanse eden kişi/kurumdur. Yatırımcının ortaya koyduğu tek değer sermayedir ve bu sermayeyi riske atmaktadır. Girişimci ise belki bir miktar sermayesi ile beraber esas olarak iş fikrini (fırsat), emeğini, bilgisini ve zamanını ortaya koymaktadır. Buradan hareketle girişimcinin riskinin yatırımcıya kıyasla daha fazla olduğu hatta bazen hayati riskler bile üstlendiği söylenebilir. Bahsi geçen dönemde girişimci ve yatırımcı kavramlarının bir biri içine geçtiği durumlara da oldukça sık rastlanmaktadır (İnalcık, 2014, s. 294295).Girişimcinin girişimini gerçekleştirebilmesi ve sürdürebilmesi için elverişli bir ortama ihtiyacı vardır. Girişimcilik iklimi de denilen bu ortam ulusal ve uluslararası iktisadi durum, merkezi ve yerel idare politikaları, vergi uygulamaları, fon talebi karşılama olanakları, rekabet yapısı gibi faktörlerden oluşmaktadır. Girişimci, bu faktörlerin hiçbirisine ontolojik olarak doğrudan bağlı değildir. Hatta olumsuz olarak algılana bir faktör bazen girişimciye yeni fırsatlar sunmaktadır. Ancak elverişli bir girişimcilik ortamında başarı şansının yüksek olduğu bir gerçektir (Başar, 2014, s. 86).

\section{Osmanlı İmparatorluğu'nda Girişimcilik ve Girişimcilik Ortamı}

Osmanlıdaki girişimcilik ortamını açıklayabilmek için öncelikle Osmanlı Devletinin iktisadi yapısının temelini oluşturan ve bu yapıya yön veren temel

\footnotetext{
3 İnalcık, “Devlet-i ‘Aliye: Osmanlı İmparatorluğu Üzerine Araştırmalar-I” adlı eserinde entrepreneur (girișimci) sıfatından "kapitalist yatırımcı" olarak bahsetse de aynı eserin farklı bölümlerinde girişimci (tüccar, zanaatkâr, imalatçı) ile yatırımcı kavramlarını farklı boyutlarda ele almıştır (İnalcık, 2014, s. 280). Tüccarların diğer sektörlerde yatırım yapması, memuriyet başta olmak üzere diğer meslek erbaplarının da ticarette yatırım yapması nedeniyle kavramların bir biri yerine veya bir arada kullanıldığı düşünülebilir.
} 
kavramlara değinmek zorunludur. Bu yapı ne kadar iyi incelenirse bahsi geçen dönemdeki bir Osmanlı girişimcisinin içinde bulunduğu ortam o denli iyi anlaşılabilir. Osmanlı girişimcisinin varlık nedenini doğrudan bu iktisadi yapıya bağlayamasak da girişimciye olan etkisinin büyük olduğu muhakkaktır. Aşağıda değinilmekte olan; iaşe, fiskalizm ve gelenekçilik ilkeleri açıklanmadan yapılacak bir "Osmanlı İmparatorluğunda Girişimcilik" değerlendirmesinin, bu günün liberal ekonomi bakış açısı nedeniyle anakronizme kapılma ihtimali ortaya çıkmaktadır. Ayrıca Osmanlı İmparatorluğundaki girişimcilik kültürünü anlamak için ise dönemin ticaret ve zanaat anlayışının ve işleyişinin iyi incelenmesi gerekmektedir.

\section{Osmanlı İmparatorluğu'nun İktisadi Yapısına Yön Veren İlkeler}

Klasik (15. yüzyıl ile 17. yüzyıl arası) dönemde Osmanlının iktisadi yapısı kendi kendine yeten "büyük iktisadi ünite" olarak kabul edilmektedir (Akdağ, 1949, s. 508-509). Bu büyük iktisadi ünitede klasik dönemde etkili olmuş üç temel ilkeden söz edilmektedir. Bunların ilki iaşe ${ }^{4}$ (provizyonizm)ilkesidir. Weber (1995, s. 99) ekonomik etkinlik kavramını açıklarken amacın tüketicinin gereksinimlerinin karşılașılmasından çok girişimcilerin fayda sağlaması olduğunu iddia etmektedir. Buna karşılık iaşe ilkesi, tüketicilerin gereksinimlerini ön planda tutmaktadır. Osmanlı da iaşe ilkesi ile tüketici penceresinden bakarak iktisadi sisteme tüketici lehine sık sık ve sistemli olarak müdahale etmiştir. Bunlara örnek olarak birkaç hüküm şöyle sıralanabilir: Edirne'de çekilen et sıkıntısı nedeniyle Eflak ve Boğdan'dan gelen sürülerin on beşte birinin Edirne'ye sevkine dair hüküm ${ }^{5}$. İstanbul için kazalardan koyun ihraç edecek celeplerin tespit edilip üzerlerine yazılan mevsim koyunlarını zikredilen tarihe kadar İstanbul'daki kasaplara teslim etmelerine dair hüküm6. İstanbul'da üzüm sıkıntısı çekilmemesi için çeşitli kazalardaki üzümlerin şarap yapmak için satılmamasına dair hüküm7. Samsunda yetişen soğanların çeşitli kişiler tarafından satın alınıp depolanması sonucu İstanbul'da soğan darlığı yaşanması ve bunu önlemek için soğanın günlük narh üzerinden alınıp gemilerle İstanbul'a gönderilmesine dair hüküm ${ }^{8}$. Bu müdahalelerde temel ihtiyaç malı arzının bol olması, kalitesinin yüksek olması ve ucuz olması amaçlanmaktadır. Bu ilkeye göre ihracat öncelikli bir hedef değildir. İhracat ancak ülke içinde değeri kalmayan malların resmi izin çerçevesinde satılması ile gerçekleşmektedir. Buna karşılık ithalat, halkın ihtiyaçlarını karşıladığı için

\footnotetext{
4 İașe kelimesi "iyș” (yașamak) kökünden gelmekte ve yedirip içirme, barındırma, geçindirme anlamına gelmektedir (www.tdk.gov.tr, Erişim Tarihi: 21.06.2017). Geçinme ve yaşamak için gerekli olan maddeleri temin etme anlamına gelen maaş kelimesi de aynı kökün farklı bir halidir (Haldun, 2010, s. 608).

57 Numaralı Mühimme Defteri (975-976/1567-1569) Özet-Transkiripsiyon-I,-Ankara 1997 s.23.

612 Numaralı Mühimme Defteri (978-979/1570-1572), Özet-Transkiripsiyon ve İndeks I, .Ankara 1996, s.249.

76 Numaralı Mühimme Defteri (972/1564-1565), Özet-transkripsiyon ve indeks I, Ankara, 1995, s.46.

${ }^{8} 5$ Numaralı Mühimme Defteri (973/1565-1566), Özet ve İndeks, Ankara 1994, s. 24.
} 
iaşe ilkesine uygundur. Bu yüzden ithalat kolaylaştırılmışken ihracat ancak özel izinlerle yapılabilmektedir (Genç, 2007, s. 45-47).

Bir diğer ilke olan fiskalizim (gelircilik) ilkesi ile devlet gelirlerinin maksimize edilmesi amaçlanmaktadır. Dış ticaret ve içerideki ekonomik faaliyetlerden alınan vergiler ile devletin gelirleri, idari masraflar ve savaş bütçesini karşılamak üzere arttırılmak istenmektedir. Pamuk (2001, s. 12)'a göre merkezi idare, uzun vadede vergi oranlarında değişiklik yapmasa da kriz durumlarında vergileri yükseltmekte tereddüt etmemektedir. Fiskalizm ilkesi uygulanırken hem gelirleri arttırmak hem de harcamaları azaltmak amaçlanmıştır. Ancak Osmanlı gelirleri yükseltmek konusunda, diğer ilkelere verilen öncelikler ve iktisadi dengeleri bozma endişesi nedeniyle zorluklar yaşamıştır (Genç, 2007, s. 50-51).

Diğer iki ilkeye oldukça bağlı olan üçüncü ilke ise gelenekçiliktir (Pamuk, 2001, s. 12). Gelenekçilik ilkesi daha çok, Osmanlının miras devraldığı İslam devletlerinin yaklaşımlarına dayanmaktadır. Osmanlı Devletinin kuruluş döneminde, Selçuklu Devletinin ilmi ve iktisadi kadroları, Bizans şehirlerini ele geçirilmesinin ardından Osmanoğulları'nın hizmetine girmeye başlamıştır. Özellikle sınırların Balkanlara doğru genişlemesiyle Selçuklunun dağılan sosyal, siyasal ve ekonomik yapıları Osmanlının yeni temel kurumlarını olușturmuştur. Kısaca tanımlamak gerekirse, şeriata aykırı olmadığı müddetçe eskiden beri ola gelen iktisadi hükümlerin uygulanması gelenekçilik ilkesini teşkil etmektedir (Akdağ, 1949, s. 505).

$\mathrm{Bu}$ ilkeler kendi aralarında kıyaslandığında iaşe ilkesinin diğer iki ilkeye karşı ağır bastığı görülmektedir. İaşe o kadar önceliklidir ki yerli üreticiyi fiskal çıkarlar için korumak Osmanlı Devletinin hiç aklına gelmemiş gibidir (İnalcık, 2000, s. 87). Ayrıca Osmanlı, sosyal refah sağlamayı adaletin bir boyutu olarak görmektedir. İktisadi kararlar için bu sosyal refah gerekçe gösterilmektedir. Devletin gelirlerini arttırmak için iktisadi dengenin bozulması bunalıma yol açacak ve sosyal refah ilkesinden uzaklaşılacaktır. Bu bakış açısı nedeniyle, Osmanlının iktisat sistemi talep yönlü değil arz yönlü olmuştur. Talebin arttırılmasına yönelik kapitalist sistem iaşe ilkesiyle çelişmektedir (Tabakoğlu, 2008, s. 146-147).

\section{Osmanlı İmparatorluğu'nda Girişimcilik Kültürü}

İbn Haldun (2013, s. 1425) geçinmek için gerekli olan kazanç yollarından bahsederken memuriyet, avcılık, hayvancılık ve çiftçilikten sonra ticaret ve zanaatkârlıktan bahseder. Girişimciliğin daha çok ticaret ve zanaatkârlık ekseninde toplanmasından dolayı bu iki meslek erbabına odaklanılmıştır. Girişimcilik türlerinden birisi olan ticaret, Osmanlı'da ve miras aldığı İslam Devletlerinde oldukça yaygındır. Kur'an-ı Kerimde ticaretten ve ticaret ahlakından bahseden ayetler bulunmaktadır (Örneğin; Nisa 29. ayet ve İsra 35. ayet). Hz. Peygamber'in "Güvenilir, dürüst tacir ahirette peygamberler, Sıddıklar ve şehitlerle beraberdir." ve "Rızkın onda dokuzu ticarettedir." hadisleri (Rudani, 2012, s. 120), ticareti Müslümanlar nazarında övülmüş bir 
meslek haline getirmektedir. Fıkıh kitaplarında; ticaret kaidelerine, yasaklara, sınırlamalara ve hukuki sonuçlara ayrıntılı olarak değinilmektedir. Zekâta konu ticari malların sarfında, borçlular ve yolda kalmışların da olması girişimcilerin cesaretini arttırmaktadır (Kallek, 2012, s. 134). 15. yüzyılın ikinci yarısında Osmanlı padişahına verilen bir öğütte tüccarın teşvik edilmesinden, korunmasindan ve bu ticaret sayesinde ülkede refah ve ucuzluğun sağlanacağından bahsedilmektedir (Braudel, 2004, s. 556).

İncelenen dönemde, doğal olarak iç ve dış ticaret yoğun olarak gerçekleşmektedir. Ancak; Osmanlı'nın, Avrupa ile olan ticaretine birçok çalışma yapılmışken iç ticareti, Mısır, İran ve Hindistan ile olan dış ticareti ihmal edilmiştir. Bunun nedenlerinden birisi olarak Avrupalı tüccarların diplomatların ayrıntılı raporlarının çokluğu gösterilmektedir. Diğer bir neden ise araştırmacıların Avrupa dilleri ile yazılmış raporları diğer dillerde yazılanlara göre daha çok tercih etmesidir. Avrupa dışına yapılan dış ticaret ve iç ticaret Osmanlı kaynaklarına dayanan araştırmaların artmasıyla anlaşılmaya başlanmıştır (Quataert, 2006, s. 943).

\section{İç Ticaret}

Faroqhi (2006, s. 601-603)'ye göre 17. yüzyll ve öncesinde, Osmanlıdaki ticaret üstünlüğünün Avrupalı merkantilistlerin elinde olduğu varsayımı geçerliliğini yitirmiştir. 16. yüzyıl ve sonrasında köylülerin bile mallarını pazara sürerek ticarette rol aldığı görülmektedir. İç ticaretin, hem Ankara ve Bursa'da hem de Balkan kasaba ve şehirlerinde hatırı sayılır bir sermaye birikimine yol açmıştır. Bu durum; 16. yüzyılda, Osmanlının, iç ticari faaliyetleri engellemeden vergi almanın yollarını aramasından anlaşılabilmektedir. Buradan 16. ve 17. yüzyılda toplumun her kesiminden bireylerin iç ticarette rol üstlendiği görülmektedir. Tüccarlar, yerel ekonominin önemli bir fonksiyonunu oluşturmaktadır. Ayrıca faaliyetleri bazen hammadde fiyatlarını arttırmakta ve kimi zaman yerel esnafin faaliyetlerinin olumsuz etkilemektedir. Merkezi idarenin tüccarları korumak kadar önem verdiği diğer görev onları kontrol etmektir. Osmanlının, zanaatkârları kolayca kontrol ederken tüccarları kontrol etmekte oldukça zorlandığı anlaşılmaktadır (Pamuk, 2005, s. 8-9).

\section{Dış Ticaret}

Günümüzdeki yaygın görüşün aksine 15. ila 17. yüzyıllar arasında Osmanlıdaki Müslüman tacirlerin dış ticaretteki rolü oldukça güçlüdür. Bazı sektörlerdeki ağırlıklar bir millete (Ermenilerin ipek ticareti gibi) ya da gruba kaymış gibi gözükse de sektörün tamamen tekele alındığını söylemek yanlıștır. Burada, sektörel uzmanlaşmanın ve bölgesel kümelenmenin geliştiği söylenebilir (Faroqhi, 2006, s. 722). İnalcık (2014, s. 281)'ın Evliya Çelebi'den aktardığına göre İstanbul'da bölgeler arası ticaretle uğraşanlar üç temel gurup altında toplanmaktadır. Birinci gurup Müslüman ve Rum gemi kaptanlarıdır. İkinci gurup bedestende oturan armatörlerdir. Vezir gibi giyinen ve çok zengin 
olan bu gurubun Müslüman olduğunu Evliya Çelebi’nin “Pirleri Hazret-i Peygamberdir" ifadesinden anlaşılmaktadır. Üçüncü grup ise hemen her milletten oluşan arpa-buğday ticaretiyle uğraşan toptancllardan oluşmaktadır.

Bahsi geçen dönemde, Karadeniz ticaretinde Anadolulu Müslüman tüccarların önemli etkisinin olduğu görülmektedir. Kefe, Akkerman ve Kilia gümrük kayıtlarına göre Kırım'a gelen ürünün büyük çoğunluğunun Anadolulu Müslümanlar tarafından sağlandığı anlaşılmaktadır. Bu kayıtlara göre Kefe'ye denizden gelen 157 tüccardan 130’u (\%82'si) Müslümandır (İnalcık, 2014, s. 273). Bu bölgeler arası ticaret ile Anadolu'daki ticaret ve imalatın gelişmesinde etken olan tek pazarın iç pazar ve büyük şehirler olmadığı söylenebilir. Yine 15. ve 16. yüzyılda Balkanlar'a bakıldığında, savaşlara rağmen ticari bir canlılık göze çarpmaktadır. Macaristan'la yapılan ticaret sayesinde zenginleşen Osmanlı askeri sınıfına mensup tüccarlar bulunmaktadır (Faroqhi, 2014, s. 360-361). 7 Numaralı Mühimme Defterindeki (1997) 61 numaralı hükümde; vefat eden Hassa tacirin yerine görevlendirilen yeni Hassa tacirine hitaben, gerektiğinde kendisine yardımcılar sağlaması için Moskova Kralına name gönderildiğinden bahsedilmektedir. Yine 5 Numaralı Mühimme Defterindeki (1994, s. 207-208) hükümde Moskova Kralına hitaben, gönderilecek hassa tacire gerekli kolaylığın yapılması ve satın alacağı mallardan gümrük vergisi alınmaması talep edilmektedir. $\mathrm{Bu}$ ve benzeri emirler 16. Yüzyllda Rusya ile olan ticaretin önemine işaret etmektedir.

Osmanlı uyruklu Müslüman tüccarların Avrupa devletleri ile doğrudan ticaret yaptıkları bilinmektedir. Hatta İtalya panayırlarına katılan Türk tüccarlar Venedik'in Levant ticaretini etkileyebilecek boyuta ulaşmıştır (İnalcık, 2014, s. 274). Bunun kaynağı Osmanlı ile Venedik arasındaki imtiyazlardır. Başta, tek taraflı ve Venedik lehine olan imtiyazlar Celebi Mehmed'in 6 Kasım 1419 tarihli ahitnamesi ile karşılıklı imtiyazlar olarak düzenlenmiştir. Bu ahitnameye göre Venediklilere tanınan serbest ticaret ayrıcalıklarına karşı Türk tacir ve tebaasının hiçbir yerde engellenmemesi gerektiği belirtilmiştir. Ahitnameye dayanarak, Osmanlı yönetiminin satılmak üzere gönderdiği ürünlerden bac, gümrük, dellâliye ve ısdariye gibi vergilerin hiçbirisi alınmamaktadır (Uzunçarşıll, 2011, s. 684). Böylece Ege adalarından başlayarak Venedik'e kadar olan bölge Türk tüccarlara açlmıştır. Venedik'e giden tüccarlar kabaca iki gruba ayrılabilir. Birinci grup Saray mensuplarının siparişlerini getirmek üzere giden özel tüccarlardır (hassa tacir veya memur-ı mahsus). İkinci grup ise korsan tehdidi ve navlun maliyeti nedeniyle gruplar halinde hareket eden asıl tüccarlardır. Bu ticaretlerde hem deniz yolu hem de İstanbul'dan Spalata (Split) limanına kadar kara yolu ve Adriyatik hattı kullanılmaktadır. Türk tüccarların Venedik'te kalma süreleri artınca şehirde ticarethane açmaya başlamışlardır. Bunun sonucu olarak Venedik'te, Türk tüccarların topluca faaliyet gösterebileceği Fondaco Dei Turchi (Türklerin Fondokosu) adında bir iş hanı (ticaret merkezi) tahsis edilmiştir (Turan, 1968, s. 249-261).

Her kime ait olursa olsun ihraç olunacak ürünlerin hepsi Osmanl idaresinin iznine tabidir. Mallarının izinsiz ihraç edildiğine dair iddialar en üst 
makamlarca araştırılmaktadır ve tespiti halinde hapisle cezalandırılmaktadır (Bkz. 6 Numaralı Mühimme Defteri (972/1564-1565), (Özet-Transkripsiyon ve indeks), C.1, Ankara, 1995, s.29 ve 3 Numaralı Mühimme Defteri (966968/1558-1560) Özet ve Transkripsiyon, Ankara, 1993, s.14-15). Ürünler ülkeden çıkmadan önce kontrolden geçmektedir. Örneğin, gönderilecek kumaşların sağlamlığına, renginin sabit olup olmamasına, ölçüsünün tutup tutmamasına iyice bakıldıktan sonra miri damgası ile damgalanmaktadır. Bu kalite kontrol politikası, Avrupa'da uzun yıllar Türk imalatlarının (daha pahalı bile olsa) revaçta olmasına neden olmuştur (Uzunçarşıll, 2010, s. 685).

\section{Zanaatkârlık}

Öncelikle Zanaatkârlığın ya da esnaflığın girişimcilik kavramın içerisinde olup olmadığına değerlendirilecektir. "Girişimcilik Kavramı ve Tarihçesi" bölümünde daha detaylı değinilmekle beraber kısaca, kendi ürettiği ürünü satan zanaatkâr girişimci olarak tanımlanmaktadır. Ayrıca sanayi devrimi öncesinde ağır sanayi olarak sayılabilecek üretimler devletler eliyle yapılmakta iken küçük ve orta ölçekli imalatların nerdeyse tamamı zanaatkârlar tarafından gerçekleştirilmektedir (Kütükoğlu, 1999, s. 606-6014). Zanaatkârlı̆̆ı dışarıda bırakan bir girişimcilik tanımlaması, girişimcilik kavramını sadece ticaret ile sınırlanmasına yol açabilmektedir. Bu kapsamda, ortaya sermaye koyarak hammadde, teçhizat alan ve kendi emeğini ortaya koyarak küçük ölçekli ürün üreten bir zanaatkârı girişimci olarak tanımlamak yerinde olacaktır. Nispeten orta büyüklükte imalat yapan girişimcilere ise sanayi başlığı altında değinilmektedir.

Osmanlı'da zanaatkârlık Selçuklu ve İlhanlı geleneğinin bir uzantısı sayılabilir. Ahiyanı Rum denilen ve Osmanlının kuruluşunda önemli rol oynayan derviş guruplarının aynı zamanda çiftçi ve/veya zanaatkâr oldukları bilinmektedir. Bu çiftçi/zanaatkâr dervişler, fütüvvet ${ }^{9}$ ilkesi ile hareket edip ordulardan önce bir manevi fetih gerçekleştirmektedir. Örneğin; Osman Gazi'nin kayınpederi olan Şeyh Edebali'den dünyalığı (malı, mülkü) ve hayvanı çok olan bir derviş olarak bahsedilir (Barkan, 2002, s. 133-154). Yine; 15. yüzyılda Bursa'da, yaptığı ekmekleri ücretsiz olarak dağıtan Somuncu Baba (Şeyh Hamîdüddin Aksarâyî) da zanaatkâr dervişlere örnek gösterilebilir (Şahin, 2009, s. 377). İbn Battuta (2010, s. 341) seyahatnamesinde ahi (ahı) kavramını "sanatının ve zanaatının erbabını toplayan ve işi olmayan genç bekârları da bir araya getiren adam" olarak tarif eder. Ahilerden olan ve yaklaşık 200 kadar zanaatkâra liderlik yapan bir derici ustasının davetine icabet eden İbn Battuta, gösterişsiz giyinen bu zanaatkârın cömertliğinden bahsetmektedir. Ahi geleneğine mensup zanaatkârların, fütüvvet ve mesleklerinin dıșında üstlendikleri başka görevler de bulunmaktadır.

\footnotetext{
${ }^{9}$ Fütüvvetin kelime anlamı gençlik, kahramanlık, cömertliktir. Fütüvvet hareketi ilk ortaya çıktığında tasavvufi bir hareket olsa da 13. yüzyıldan itibaren sosyal, ekonomik ve siyasi bir yapıya bürünmüştür (Uludağ, 1996, s. 259). Fütüvvet ilkesinin Osmanlının kuruluşunda oynadığı rol için Ömer L. Barkan’ın “Osmanlı İmparatorluğunda Kolonizatör Türk Dervişleri” isimli makalesi incelenebilir.
} 
Misafirlerin ağırlanması, bölgenin ve yolların asayișine katkıda bulunulması ve esnafın idaresi bunlara örnek olarak verilebilir. Ayrıca Ahilik adap, usul ve erkânını açıklayan fütüvvetnâmeler ${ }^{10}$ esnafın ve çalışanların ahlaki ve sosyal disiplinini sağlamakta önemli yer tutmuştur (Ocak, 1996, s. 265).

Bahsi geçen dönemde Selçuklu'dan miras alınan ahilik sistemi, zanaatkârların ve muhtelif sanat erbabının bir araya geldiği lonca teşkilatına dönüşmeye başlamıştır. Her bir esnaf örgütünün esnaf şeyhi, kethüda, yiğitbaşı ve ehl-i hibre gibi azaları bulunmaktadır. Esnaflar tarafından seçilen bu heyet idarece de onaylandıktan sonra göreve başlamaktadır. Bu yapı, esnafın genel durumunun takibinden başka devlet ile esnaf arasındaki köprüyü de sağlamaktadır (Uzunçarşıll, 2010, s. 689). Esnaf örgütü kendi içindeki çoğunlukla; ustalık, kalfalık şartları, çıraklık süreleri çalışma şartları, malın kalitesi, dükkânların yeri gibi konulara karar vermektedir. Belirlenen hususlar kadı tarafından örfi ve şeri hukuka göre incelendikten sonra Divân'a arz edilmektedir (Genç, 2007, s. 296). İstanbul'da 1109 loncada örgütlenmiş 126.000 ila 260.000 arasında zanaatkâr olduğu aktarılmıştır. Meyhanecilik gibi şeriata göre Müslümanlara kapalı olan meslekler dışında tamamen Müslümanlardan ya da tamamen gayrimüslimlerden oluşan lonca ile karşılaşılmamıştır. Ancak karma loncaların ileri gelenleri çoğunlukla Müslümanlardan seçilmektedir (Faroqhi, 2006, s. 713-714). Buna dayanarak Osmanlı Devletindeki zanaatkârların çoğunlukla Müslüman Türklerden oluştuğu söylenebilmektedir.

Bir şehir veya kazada hangi esnaf türünün kaç adet dükkân açabileceği belirlenmiştir. Yine o branştaki usta ve kalfa sayısı da sınırlandırılmıştır. Ancak ihtiyaç olduğunda esnaf örgütlerinin önerisi/görüşü ve idarenin müsaadesiyle; dükkân, usta veya kalfa sayısı arttırılabilmektedir. Bir çırağın kalfa ya da bir kalfanın usta olması törenle gerçekleştirilmekte, isimleri ve dereceleri deftere kaydedilmektedir. Bu sistem sayesinde, önüne gelenin usta olması ve dükkân açması engellenmektedir (Uzunçarşıll, 2010, s. 690). Usulsüzlüğün engellenmesi ve hata payının azaltılması için, esnafın kullanacağı ölçü ve tartı birimlerini damgalattırması istenmektedir (Tabakoğlu, 2008, s. 238). Ölçüde sapma, kalitesiz mal yapma, narha (fiyat haddine) uymamak gibi hususlar \%5 ve altında bir oranda kaldığı müddetçe insani bir hata olarak görülmektedir. $\mathrm{Bu}$ oranın üzerindeki sapmalar ise tekrarlanamadığı müddetçe kısa süreli olarak cezalandırılıp affedilmektedir. Bazen esnaf örgütü içerisinden; ağır ceza, dükkân kapatma, meslekten ihraç gibi taleplerle gelinse de idare çoğu zaman uzlaştırıcı, yatıştırıcı kararlar almaktadır. Esnaflıktan çıkarma cezası çok nadir uygulanmakta ya da kısa süreli uygulanmaktadır (Genç, 2007, s. 298-299).

Osmanlı'daki esnaf örgütü sisteminin Avrupa'daki benzer sistemlere göre daha esnek olduğu söylenebilir. Örneğin Bursa'da lonca kaydı tutulmamış ve meslek geçişleri kolayca sağlanmıştır. Vergisini ödeyen bir zanaatkârın lonca kaydının olmadığını iddia etmenin zor olduğu belirtilmektedir (Faroqhi, 2006,

\footnotetext{
${ }^{10}$ Fütuvvetnâme, fütüvveti konu alan, fütüvvetin usulleri ve yapıları hakkında bilgi veren eserlerdir. Ancak burada konusu geçen anlamıyla fütüvvetnâme, 13. yüzyıldan itibaren Anadolu'da gelişmeye başlayan Ahi teşkilatlarıyla ortaya çıkan ahi fütüvvetnâmeleridir (Ocak, 1996, s. 265).
} 
s. 711-712). Avrupa'da ise şehir yetkilileri pazarın örgütlenmesini ve gözetimini sıkı bir şekilde ele almıştır. Sicilyalı bir satıcı tarifenin biraz üstünde fiyat istese kürek cezasına mahkûm olabilmektedir. Chateaudum (Fransa) kentinde üçüncü kez kusurlu bulunan firıncılar hiçbir önlem alınmadan yük arabasının tepesinden atılmaktadır (Braudel, 2004, s. 6). Hayvan ihracatının yasak olduğu 16. yüzyıl İngiltere'sinde küçükbaş hayvan ihraç eden kimsenin malları müsadere edilmekte, ayrıca bir yıl hapis cezasının ardından pazarın kurulduğu bir günde halk önünde sol eli kesilmektedir. Aynı ceza ikinci kez işlendiğinde ise idam cezasına çarptırılmaktadır. Bu sert cezalar Avrupa'da 1417 yılına kadar geri gitmektedir ve ancak 17. yüzyılda kaldırılabilmiştir (Smith, 2015, s. 717).

\section{Sanayi Üretimi}

Osmanlı İmparatorluğu'nun klasik döneminde, halkın ihtiyacı olan hemen hemen tüm metal eşya içeride yapılmaktadır. Dışarıdan metal eşya ithal edildiğine dair bir kanıt yoktur. Giyecek başta olmak üzere birçok işlenmiş mamul dışarıdan gelse de içeride benzer üretimin olmadığını söylemek yanlıştır. Örneğin, Anadolu'nun geniş sahasına yayılmış kuvvetli bir dokuma sanayi bulunmaktadır. Deri sanayisi ise Avrupa'dan ileridedir ve deri ihraç ürünleri arasındadır (Akdağ, 1949, s. 509). Ağır sanayide ise devletin doğrudan müdahalesi hissedilmektedir. Yine madenlerin çıkartılması devletin yönetimiyle olmaktadır. Şaplar bazen hükümet tarafından işletilmekte bazen ise iltizama verilmektedir. Küre bakırı; Sivas, Tokat ve Amasya esnafına verilmekte ve fazlası İstanbul'a sevk edilmektedir. Bakırın yoğun talep nedeniyle İran'a kaçırılmamasına dikkat edilmektedir (Uzunçarşıll, 2010, s. 682-683).

Osmanlı; yetersiz üretimin tüketicinin daha yüksek fiyat ödemesine, aşırı üretimin ise üreticinin düşük fiyat yüzünden zarara uğramasına yol açtığını uzun tecrübe ve gelenekleriyle bilmektedir. 15. yüzyll sonlarında Bursa'daki lonca, halkın yoğun talebi sonucu ucuz ipekli kumaş üretmeye başlamıştır. Yönetmelikleri hiçe sayan bu girişim, her kumaş türündeki ipek, boya miktarı ve kalitesini ayrıntılı bir şekilde belirten bir düzenlemeyle engellenmiştir. Buradan devletin ucuz ama kalitesi düșük ürüne halkın yoğun talebine rağmen izin vermediği anlaşılmaktadır (İnalcık, 2000, s. 90-91). Sıkı denetime rağmen tekstil imalatı Avrupa ile yarışır bir konumda bulunmaktadır. Avrupa'nın lüks kumaşlarının bile Bursa boyahanelerinde boyanması söz konusudur. III. Murat (1574-1595) zamanında İngiltere'ye dokuma ve boyama teknolojisi ihraç edildiği bilinmektedir (Tabakoğlu, 2008, s. 250). Sonuç olarak, 1760'lara kadar geçen süre değerlendirildiğinde; Osmanlı imalatçısının, uluslararası ticarete başarılı bir şekilde katıldığı söylenebilir (McGowan, 2006, s. 819). 


\section{Kredi ve Sermaye İmkânları}

İncelenen dönemde bir zanaatkârın kullanacağı iş, alet ve makinaları kolayca ulaşabileceği kadar ucuzdur. Girişimcinin finanse edemeyeceği, görece pahalı bina ve sabit tesislerin çoğu ya devletin ya da bir vakfın mülkiyetindedir. Ayrıca devlet, ziraat ve esnaflıkta doğrudan üretim araçları sağlayarak yatırımlar da yapmaktadır (Genç, 2007, s. 236,341). Bu imkânlara rağmen bazen, girişimciler ve özellikle tüccarlar nakit paraya yani sermayeye ihtiyaç duymaktadır. Bahsi geçen dönemde girişimcilere sermaye sağlayan, değişik özellikte birçok yapı bulunmaktadır.

Bunlardan ilki ortaklık türleridir. Girişimci ve yatırımcıyı bir araya getiren çeşitli ortaklık türleri bulunmaktadır. Mudaraba (commenda), mufavada, musharaka, vücuh, kapan gibi çeşitleri bulunan bu ortaklık türlerinin en sık karşılaşılanı mudaraba'dır. Avrupa'da da commenda adıyla yapılan mudaraba ortaklık türünde, kapital sahibi yatırımcı girişimci ile kar zarar ortaklı̆̆ına girmektedir. Kâr genellikle 3/4'e 1/4 oranında paylaşılsa da bu oran karşılıklı olarak esnetilebilmektedir (Çizakça, 1996, s. 3-7). Mudaraba'nın ticaret için değil de imalat için yapılanına şirketil sanayi denmektedir. Mudaraba'da bir taraf sermaye koyarken diğer taraf bilgi ve becerisi ile ticaret yapmakta, şirketil sanayi ortaklık türünde ise bir taraf sermaye koyarken diğer taraf yeteneğini ve emeğini ortaya koyarak imalatı gerçekleştirmektedir (İnalcık, 1967, s. 101).

Girişimcilere nakit sağlayan ikinci unsur ise para vakıflardır. Girişimci ihtiyaç duyduğu sermayeyi nakit sağlayan vakıftan almakta ve daha sonra faiziyle geriye ödemektedir. 1456-1551 yılları arasında İstanbul'da kurulmuş olan 2.517 vakfın \%46'sı nakit sermaye sağlayan para vakfıdır. Yine Bursa'da 761 adet para vakfının girişimciye nakit sermaye sağladığı bilinmektedir. Şeyhülislam Ebussud Efendi, faizle borç vermenin haram olduğunu ancak bu vakıfları kapatmanın halkı zor durumda bırakacağını belirtmiş ve olumlu yönde fetva yayınlamıştır (Çizakça, 2006, s. 14). Bu fetva ve idarenin desteği ile para vakufları Anadolu ve Rumeli'de hemen hemen her şehirde gelişimine devam etmiştir. Girişimciler başta olmak üzere toplumun nakit paraya ihtiyaç duyan hemen hemen her kesimine, piyasanın altında bir faiz oranıyla kredi sunan bu vakıflar, bankacılığın gelişmediği bir dönemde girişimcilik ortamına olumlu katkı sağlamıştır (Aydın, 2014, s. 88).

Girişimciye sermaye sağlayan üçüncü yapı; zengin tüccarların, askeri sınıf mensuplarının ve çiftlik sahiplerinin yaptığı tefecilik faaliyetleridir. Borç para verenlerin çoğu Müslümanlardan oluşmaktadır. İkinci sırada Hristiyanlar ve ardından Yahudiler gelmektedir. Tefecilik Osmanlı yönetimi tarafından hoș karşılanmasa da doğrudan müdahalelere pek rastlanmamaktadır. Borcunu ödeyemeyenler Divan-ı Hümayuna başvurmakta ve burada sicile kaydedilmektedir. Anlaşmazlıklarda idare, iki tarafın rızasını alarak orta yol bulmaya çalışmaktadır (Aydın, 2010, s. 443). Devlet bazen tefecilikle uğraşanları ya da aşırı zenginleşenleri İstanbul'a celep (kesilecek hayvanların ticaretini yapan kimse) tayin ederek bir nevi cezalandırmaktadır. Etin satışı için 
belirlenen narhlar (fiyat hadleri) genellikle celeplerin zarar etmesine neden olmaktadır (Tabakoğlu, 2008, s. 245). Yine de; birçok Osmanlı kentindeki tereke (miras) defterleri incelendiğinde, Müslüman girişimcilerin (daha çok tüccar ve çitlik sahibi sınıfın) hatırı sayılır bir meblağı borç verdiği ve ciddi bir servet bıraktığı görülmektedir. Osmanlının klasik döneminden 18. yüzyıl sonlarına kadar birçok büyük şehirde önemli kapital birikimleri gözlenmektedir (İnalcık, 2014, s. 288).

Sonuç olarak; narhlar nedeniyle esnaf ve tüccarın kar marjı \%05-\%15 aralığında iken faiz haddinin \%10-\%25 aralığında olması, esnafın ve iç ticaret yapacak tüccarın kredi almasını zorlaştırmaktadır. Kredilerin daha çok dış ticaret yapacak tüccarlar tarafından kullanıldığını söylemek daha doğru olacaktır (Genç, 2007, s. 68). Daha önce değinildiği gibi esnafın kuruluş dönemi makine-teçhizatına ve sabit değerlere (dükkân vb.) ulaşması gayet kolay olmaktadır. Dış ticarette ise girişimciler sadece tefeciye muhtaç kalmamış; para vakıfları, çeşitli ortaklık yapıları ile sermayeye ulaşmıştır.

\section{Osmanlı İmparatorluğu'ndaki Girişimcilik Anlayışının Avrupa'daki Anlayış ile Karşılaştırılması}

Osmanlı'nın klasik dönemindeki iktisadi anlayış ile Avrupa'nın merkantilist anlayışı arasında ciddi farklılıklar bulunmaktadır. Merkantilist sistemde ülkenin zenginleşmesi için ihracatın kolaylaştırılıp ithalatın sınırlandırılması gerekmektedir. Bir diğer anlayış ise işçilik maliyetinin minimize edilip diğer ülkelerdeki işçilik maliyetinin altında tutulmasıdır. Bu sistemin çalışanın lehine olmadığı daha çok zenginlerin ve güçlülerin yararına yapılan girişimleri özendirdiği söylenebilir (Smith, 2015, s. 710-712). Merkantilist sistemin esas ilgilendiği (çıkarı göz ardı edilen) tüketiciler değil, çıkarları özen ile kollanmış üreticilerdir. Bir anlamda tüketicilerin çıkarları üreticinin lehine feda edilmiștir (Smith, 2015, s. 733). Osmanlı Devletinin esas kaygısı iç pazardaki tüketicinin korunması ve devletin fiskal çıkarları iken merkantilist ekonomilerde ekonomik düzenlemeler rekabete dayalı bir uluslararası ticaretin gerekleri tarafından belirlenmektedir (İnalcık, 2000, s. 88).

Osmanlı'nın dış ticaretteki görece serbestlik ilkesine rağmen hiç koruyucu önlem almadığını söylemek yanlış olur. Daha önce belirtildiği gibi idare, iaşe ilkesi gereğince hammaddelerin ihracatına sınırlamalar koymaktadır. Benzer yasaklamalar bazen esnafın hammadde sıkıntısı çekerek şikâyet etmesi sonucu da getirilmektedir. Esnafın hammadde tedarikinde Avrupalı tüccarlar karşısında zorlanması sonucunda devlet önlem almaya çalışmıştır. Birçok hammaddenin kapitülasyon verilen devletler dâhil Avrupalı tüccarlara satışı yasaklanmıştır (Akdağ, 1949, s. 511-512).

$\mathrm{Bu}$ noktada, aynı dönemde Avrupa'daki girișimciliğe de kısaca değinmekte fayda görülmektedir. Fransa'da uzun süre birinci olan zanaat tipi endüstri, modern endüstrinin arkasına ancak 1860'lardan sonra düşmüştür. Bu tarihe kadar ön endüstrinin esas çizgisi kapitalist yeniliklere karşı dirençtir 
(Braudel, 2004, s. 665). Bir diğer örnek olarak Avrupa'da doğan putting-out sistemi verilebilir. Bu sistemde esnaf tüccar için parça başı çalışmaktadır. Esnafın her aşamada kapitalist tüccara muhtaç olduğu bu üretim sistemi her açıdan sömürgeye açıktır (Akkuş, 2009, s. 53). Buradan hareketle Osmanlı'daki girişimcilik anlayışının iktisadi gelişmeler karşısında yaşadığı problemlerin başka bir biçimde Avrupa'da da yaşandığı söylenebilir.

Osmanlı esnaf sınıfının narhlar (fiyat hadleri) nedeniyle tam serbestlik içerisinde sınırsız üretim faaliyetleri içerisine girmesine olanak tanınmamıştır. $\mathrm{Bu}$ nedenle esnaf sınıfında bir kapital birikime sık rastlanmamaktadır. Ancak özellikle bölgeler arası ticaretle uğran bir tüccar, kapitalist olma imkân ve koşuluna sahip bulunmaktadır (İnalcık, 2014, s. 257). Narh sitemi, kapitalist bakış açısı ve serbest pazar anlayışı ile çelişmektedir. Ancak; Avusturya'nın Trol eyaletinde bir imalatçı tüccarın 1547 yılında \%23'lük bir kar marjı ile çalışması, makasın çok da açık olmadığının göstergelerinden biridir (Braudel, 2004, s. 770).

\section{Türleri}

Klasik Dönem Osmanlı İmparatorluğundaki Farklı Girişimcilik

Günümüzde girișimcilik; kadın girișimcilik, sosyal girişimcilik, ekolojik girișimcilik, dezavantajlı grupların (gençler, eski mahkumlar vb.) girişimciliği gibi alt başlıklarına ayrılmaya başlamıştır. Bu bakış açısından bakıldığında Osmanlının klasik döneminde bazı yansımalar ile karşılaşılmaktadır. Örneğin; 16. yüzyılda, Bursa'da ipek bükme aygıtlarının yarısı kadın girişimcilere aittir. Zengin bir kadının mudaraba usulü ile bir girișimciye sermayedar olması da gayet olağan durumlar arasındadır (Faroqhi, 2006, s. 718). İbn Battuta (2010, s. 297) Osmanlının kuruluş dönemindeki Türk kadınlardan bahsederken akıncı gibi at bindiklerinden ve pazarda yoğun ticari etkinliklerde ön sırada yer aldıklarını aktarmaktadır. Kadınların; tekstil sektörü başta olmak üzere diğer sektörlerdeki etkinliğinin temelleri, Osmanlının kuruluş dönemi ve klasik döneminde aranabilir. Dezavantajlı gruplar arasında olan bir kölenin, Bursa'da bir ipek tüccarının yanında çalıșıp azat edildikten sonra yine aynı tüccar tarafından sermaye verilerek kendi girişimini yapması sağlanmaktadır (Faroqhi, 2006, s. 722). Başka bir örnekte; Divan-ı Hümayun tarafından mal taşıyan esnaftan, yük çeken hayvanlara geri dönüşlerinde binilmemesi ve eziyet edilmemesine dair kararlar alınmıştır (Genç, 2007, s. 73).

Tüm örnekler ve daha önce değinilen ahilik teşkilatı dikkate alındığında, tanımlanması ancak günümüzde yapılmış olan girişimcilik alt türlerinin Osmanlıda karşılığı bulunmaktadır. Ahilik teşkilatı ve klasik Osmanlı zihniyetindeki alıcı değil verici insan olma yaklaşımı günümüzün sosyal girişimcilik anlayıșına önemli bir örnek teşkil etmektedir. Çağdaş kapitalist yaklaşımın "insan ekonomi içindir" anlayıșını tersine "ekonomi insan içindir" yaklaşımı, ahilik zihniyeti ile bir "sosyal girişimci sınıfın" oluşmasına imkân sağlamıştır. Kapitalizmin idealize ettiği homo economicus'un temel amacı bireysel menfaat iken Osmanlı'nın klasik döneminde toplum yararını kendi 
çıkarının üstünde tutan kanaatkâr fakat girişimci insan tipi idealize edilmiştir (Tabakoğlu, 2008, s. 147-151). Yine bu günkü yaygın kanının aksine kadınların günlük hayatın ortasındaki ticarette, esnaflıkta, imalatta ve hatta yatırımcılıkta hiç de azımsanamayacak, önemli bir rol üstlenmesi; kadın girişimciliğinin daha o günlerden geliştiğinin göstergesidir. Azat edilmiş bir köleye bile kendi işini kurması içine yardım edilmesi, hayvanlara eziyet edilmemesi için en üst makamlardan talimatların yayınlanması 20. yüzyıla kadar Dünya'da eşine zor rastlanır uygulamalardır. Dezavantajlı guruplardaki girişimciler bizzat başka girişimciler tarafından desteklenirken, ekolojik girişimcilik devlet otoritesi tarafından titizlikle dikte edilmektedir. Kısaca; günümüzde genel kabul gören, girișimlerdeki iş ahlakı, sosyal fayda ve sosyal sorumluluk anlayıșının kâr maksimizasyonunun önüne geçmesi gerektiğine dair görüş (Menteş, 2009, s. 25) Osmanlı İmparatorluğu'ndaki girişimcilik anlayışında çağının çok ilerisinde bir vizyon çerçevesinde yer almaktadır.

\section{Sonuç}

İşletme literatüründeki birçok eserde, Osmanlı İmparatorluğundaki ve Türkiye Cumhuriyetindeki girişimcilik kavramı, 19. Yüzyıldan itibaren ele alınmaktadır. Bu tarihten önceki girișimcilik faaliyetleri yok sayılmakta ya da yabancıların ve gayrimüslimlerin tekelinde olduğu kabul edilmektedir. Ancak, Osmanlı kaynaklarına dayanan araştırmaların artmasıyla birlikte Müslüman Osmanlı tebaasının ticaretteki yoğun varlığı belgelenmiştir. Osmanlı İmparatorluğunun birçok yerinde iç ticaretin Müslüman Türk tüccarların elinde olduğunu ve Akdeniz ve Karadeniz başta olmak üzere birçok bölgede yoğun dış ticaret faaliyetlerinde bulundukları aktarmaktadır. Ayrıca esnaf loncaları üzerinden yapılan değerlendirmeler ışığında Osmanlıdaki zanaatkârların büyük bir çoğunluğunun Müslüman Türklerden oluştuğu görülmektedir. Gerek birincil kaynak olarak sunulan mühimme defterlerindeki kararların gerekse Osmanlının iktisadi tarihi üzerine yazılan eserlerin değerlendirilmesi sonucunda; Osmanlı klasik dönemindeki Müslüman Türk girişimcilerin yoğun bir şekilde varlık gösterdiği, hatta birçok alanda çoğunluğu teşkil ettiği kanaatine varılmaktadır. Bu kapsamda, 19. yüzyıl öncesinde Osmanlıda girişimciliğin olmadı̆̆ı ve ticaretin daha çok gayrimüslimler tarafından gerçekleştirildiği hipotezinin geçerliliğini yitirdiği düşünülmektedir.

Osmanlıdaki girişimcilik ortamını açıklayabilmek için öncelikle Osmanlı Devletinin iktisadi yapısının temelini oluşturan ve bu yapıya yön veren temel ilkelere değinmek zorunludur. Bu ilkeler arasından iaşe ilkesinin ağır bastığı görülmektedir (İnalcık, 2000, s. 87). Ayrıca Osmanlı, sosyal refah sağlamayı adaletin bir boyutu olarak görmektedir. İktisadi kararlar için bu sosyal refah gerekçe gösterilmektedir. Bu yaklaşım Osmanlının girişimcilik kültürü ve uygulamaları açısından belirleyici bir role sahip olmuştur. Osmanlı İmparatorluğunda iş ahlakı ve sosyal sorumluluk bakımından döneminde rastlanmayan ve döneminin çok ilerisinde bir anlayışla girişimcilik 
faaliyetlerinin sürdürüldüğü görülmektedir. Benzer bakış açıları, Avrupa'da ancak 20. yüzyılın ikinci yarısında yeni yeni tartışılmaya başlanmıştır.

Osmanlının girişimcilik anlayışı ile modern girişimcilik anlayışı arasında önemli farkların da bulunduğunu belirtmek gerekmektedir. Tüketimi ve bireyselleşmeyi ön plana çıkartan ve temel amacı daha fazla satış yaparak daha fazla kâr elde etmek olan modern anlayış, Osmanlının klasik dönemindeki anlayış ile taban tabana zıttır. Osmanlının girişimcilik anlayışı, kârdan ziyade tüketiciyi ve tüketici tatminini ön planda tutmaktadır. Kalitesiz ürünlere karşı alınan sert tedbirler ve narhlar (fiyat hadleri) bunun en önemli göstergesidir. Tüketiciyi önemseyen anlayışlar nedeniyle, uzun vadede, kapitalist yaklaşımlar Osmanlı İmparatorluğundaki girişimciliğin aleyhine çalışmaya başlamıştır. Tüm olumsuzluklar ve aleyhte gelişen bakış açılarına rağmen Osmanlının klasik döneminde gelişen temel anlayışlardan, 19. yüzyılın başlarına kadar fazla uzaklaşılmadığı görülmektedir.

Çağdaş girişimcilik bakış açısında; yakın dönemde önem kazanmaya başlayan müşteri memnuniyeti, yüksek kalite, çevre bilinci, sosyal sorumluluk gibi anlayıșların Osmanlının klasik döneminde temel ve kâr uğruna feda edilemez bir durumda olduğu anlaşılmaktadır. Tüm bu değerlendirmeler kapsamında Osmanlı İmparatorluğundaki girișimcilik anlayışının günümüzdeki girișimcilik anlayıșına ıșık tutabilecek ve örnek alınabilecek özelliklerinin bulunduğu düşünülmektedir.

\section{KAYNAKÇA}

3 numaralı mühimme defteri (966-968/1558-1560) özet ve transkripsiyon. (1993), Devlet Arşivleri Genel Müdürlüğü Yay., Ankara.

5 numarall mühimme defteri (973/1565-1566), Özet ve İndeks. (1994), Devlet Arşivleri Genel Müdürlüğü Yay., Ankara.

6 numaralı mühimme defteri (972/1564-1565), (özet-transkripsiyon ve indeks). (1995) C.1, Devlet Arşivleri Genel Müdürlüğü Yay., Ankara.

7 numaralı mühimme defteri (975-976/1567-1569), (özet-transkiripsiyonIndex 1). (1997), Devlet Arşivleri Genel Müdürlüğü Yay., Ankara.

12 numaralı mühimme defteri (978-979/1570-1572), (özet-transkiripsiyon ve indeks I) (1996), Devlet Arşivleri Genel Müdürlüğü Yay., Ankara.

AKDAĞ, M. (1949). Osmanlı imparatorluğunun kuruluş ve inkișafı devrinde Türkiye'nin iktisadi yapısı, Belleten, XIII, Ankara: Türk Tarih Kurumu, 51: 497-568.

AKKUŞ, Y. (2009). XIV. ve XV. asırlarda Osmanlı ve Avrupa ekonomileri: bir mukayese denemesi, Sosyoloji Konferansları Dergisi, İstanbul Üniversitesi, İktisat Fakültesi, Sosyoloji ve Metodoloji Araştırmaları Merkezi, İstanbul, 40: 33-69 
AŞKIN, A. (2011). Tarihsel süreçte girişimcilik kavramı ve gelişimi, Girişimcilik ve Kalkınma Dergisi, Çanakkale Onsekiz Mart Üniversitesi, Biga İktisadi ve İdari Bilimler Fakültesi Yayınları, Biga, 6(2): 55-72.

ATASOY, T. (2012). Kendinizin patronu olmak: girişimcilik, 2. Basım, Ankara: ODTÜ Yayıncılık

AYDIN, H. V. (2010). 18. yüzyılda selanik kazasında tefecilerle köylüler arasındaki borç ilişkileri, XVI. Türk Tarih Kongresi, 20-24 Eylül 2010, IV. Cilt-I. Kısım, Ankara: Türk Tarih Kurumu.

AYDIN, H. V. (2014). Selanik'te 18. yüzyılın ilk yarısında para vakıfları ve kredi işlemleri, Ege Üniversitesi Tarih İncelemeleri Dergisi, 29: 87-106.

BARKAN, Ö. L. (2002). Osmanlı İmparatorluğunda kolonizatör Türk dervişleri, Türkler Ansiklopedisi, Cilt 9 Osmanlı, Ankara: Yeni Türkiye Yayınları.

BAȘAR, M. (2014). Girișimcilik iklimi, Girișimcilik ve Iș Kurma, Editör: Yılmaz Ürper, 2. Baskı, Eskişehir: Anadolu Üniversitesi Yayınları.

BATTUTA, İ. (2010). İbn Battuta seyahatnamesi, Çev. A. Sait Aykut, Cilt 1, İstanbul: Yapı Kredi Yayınları.

BRAUDEL, F. (2004). Maddi uygarlık mübadele oyunları, 2. Baskl, İstanbul: İmge Kitapevi.

Büyük Türkçe Sözlük. (2017) İaşe, (Erişim Tarihi:21.06.2017), Büyük Türkçe Sözlük. http://www.tdk.gov.tr

CANTILLON, R. (2010). An essay on economictheory (an english translation of richard cantillon'sessai sur la nature du commerce en général), Çev. ChantalSaucier, Alabama: LudwingvonMisesInstitute.

ÇIZAKÇA, M. (1996). A comparativeevolation of business partnership, Leiden: E. J. Brill.

ÇİZAKÇA, M. (2006). Cross-culturalborrowingandcomparativeevolution of institutions betweenıslamic world and the west, Relazioni Economichetra Europa E Mondo Islamico, Secc. XIII-XVIII, Edit. S. Cavaciocchi, Istituto di Storia Economica, F. Datini, Serie II, 38.

DÖM, T. S. (2015). Girişimcilik ve küçük işletme yöneticiliği, 5. Baskl, Ankara: Detay Yayıncılık.

FAROQHI, S. (2006). Ticaret: bölgesel, bölgelerarası ve uluslararası, Osmanlı Imparatorluğu'nun Ekonomik ve Sosyal Tarihi, Cilt II: 1600-16914, Çev. Ayşe Berktay vd., İstanbul: Eren Yayıncılık.

FAROQHI, S. (2014). Osmanlı'da kentler ve kentliler, Çev. Neyyir Berktay, 5. Baskı, İstanbul: Tarih Vakfi Yurt Yayınları.

GENÇ, M. (2007). Osmanlı imparatorluğunda devlet ve ekonomi, 5. Baskl, İstanbul: Ötüken Neşriyat.

GENÇ, M. (2012). Osmanlı iktisadi dünya görüşünün ilkeleri, Sosyoloji Dergisi, 3(1): 175-186.

HALDUN, İ. (2013). Mukaddime, Cilt I ve II., Yayına Haz. Arslan Tekin, İstanbul: İlki Kültür Sanat Yayıncılık.

INALCIK, H. (1967). Capital formation in the Ottoman Empire, The Journal of Economic History, Cilt. 29, No. 1, TheTasks of EconomicHistory, 29 (1): 97-140. 
İNALCIK, H. (2000). Osmanlı Imparatorluğu'nun ekonomik ve sosyal tarihi, Cilt I: 1300-1600, Çev. Halil Berktay, İstanbul: Eren Yayıncılık.

İNALCIK, H. (2014). Devlet-i 'Aliye Osmanlı Imparatorluğu üzerine araştırmalar-I, 54. Baskı, İstanbul: Türkiye İş Bankası Kültür Yayınları.

KALLEK, C. (2012). Ticaret, Türkiye Diyanet Vakfi Íslam Ansiklopedisi, Cilt 41, Ankara: Türkiye Diyanet Vakfl, 134-144.

KILIÇBAY, M. A. (1992). Braudel, Fernand, Türkiye Diyanet Vakfi İslam Ansiklopedisi, Cilt 6, Ankara: Türkiye Diyanet Vakfi, 333-335.

KÜTÜKOĞLU, M. S. (1999). Osmanlı iktisadi yapısı, Osmanlı Devleti Tarihi 2, İhsanoğlu, E. (Ed.), İstanbul: IRCIA

McGOWAN, B. (2006). Tüccar ve zanaatkâr, Osmanlı Imparatorluğu'nun Ekonomik ve Sosyal Tarihi, Cilt II: 1600-16914, Çev. Ayşe Berktay vd., İstanbul: Eren Yayıncılık.

MENTEŞ, A. (2009). Kurumsal yönetişim ve Türkiye analizi, İstanbul: Derin Yayınlarl.

OCAK, A. Y. (1996). Fütüvvetnâme, Türkiye Diyanet Vakfi İslam Ansiklopedisi, Cilt 13, Ankara: Türkiye Diyanet Vakfi, 264-265.

ÖZER, A. (2001). Girişimci sınıf, iktisadi hayat ve siyaset, Iktisadi Idari Bilimler Fakültesi Dergisi, 3/2001, Ankara: Gazi Üniversitesi.

PAMUK, Ş. (2001). A monetary history of the ottoman empire, 2. Baskl, Cambridege: Cambridge University Press.

PAMUK, SS. (2004). The evolution of factor markets in the Ottoman Empire, 1500-1800, The Rise, Organization and Institutional Framework of Factor Markets, Global EconomicHistory Network Workshop, 23-25 Haziran 2005.

QUATAERT, D. (2006). Ticaret, Osmanlı Imparatorluğu'nun Ekonomik ve Sosyal Tarihi, Cilt 2: 1600-16914, (Çev. Ayşe Berktay vd.), İstanbul: Eren Yayıncilık.

RUDANI, M. B. S. (2012). Büyük hadis külliyatı cem'u'l-fevaid, Çev. Naim Erdoğan, Cilt 2, İstanbul: İz Yayıncilık.

SMITH, A. (2015). Milletlerin zenginliği, (Çev. Haldun Derin), 10. Baskl, İstanbul: Türkiye İş Bankası Kültür Yayınları.

ŞAHIN, H. (2009). Somuncu baba, Türkiye Diyanet Vakfi Íslam Ansiklopedisi, Cilt 37, Ankara: Türkiye Diyanet Vakfi, 377-378.

TABAKOĞLU, A. (2008). Türkiye iktisadi tarihi, 8. Baskı, İstanbul: Dergah Yayınları. Dağıtım,.

TİKİCİ, M. (2009). Girişimcilik ve küçük işletmeler, Ankara: Nobel Yayın

TURAN, Ş. (1968). Venedik'te Türk ticaret merkezi, Belleten, Cilt:32, Ankara: Türk Tarih Kurumu. 126: 247-283

ULUDAĞ, S. (1996). Fütüvvet, Türkiye Diyanet Vakfi İslam Ansiklopedisi, Cilt 13, Ankara: Türkiye Diyanet Vakfi, 259-261.

UZUNÇARŞILI, İ. H. (2011). Osmanlı tarihi, Cilt 2, 10. Baskı, Ankara: Türk Tarih Kurumu Basımevi. 
WEBER, M. (1995). Toplumsal ve ekonomik örgütlenme kuramı, Çev. Özer Ozankaya, Ankara: İmge Kitapevi.

\section{Summary}

Entrepreneurship in Ottoman Empire's classical period is not adequately studied from a Business Science perspective. Majority of the related literature assumes entrepreneurship does not exist in the Ottoman Empire or it is in exclusive control of non-Muslim merchants. This study points out that the Muslim merchants were very active entrepreneurs and entrepreneurship environment in Ottoman Empire was much more favorable compared to some other European states.

Ottoman State assumes attaining social welfare is a dimension of justice and all economic decisions made by the state aim to attain this goal. This approach plays a critical role not only in determining entrepreneurship culture and related practices but also explains the advanced business ethics and sophisticated social responsibility practices of the Ottomans at the studied period. 